International Journal of Social Inquiry Cilt / Volume 14 Sayı / Issue 12021 ss./pp. 231-254

\title{
INFORMATION, MEDIA AND TECHNOLOGY SKILLS OF SPORT SCIENCES STUDENTS
}

\author{
Esin HAZAR*, Burhan ÖZKURT ${ }^{* *}$
}

Makale Geliş Tarihi-Received: 24.08.2020

Makale Kabul Tarihi-Accepted: 20.03.2021

DOI: $10.37093 /$ ijsi.950584

\section{ABSTRACT}

Although there have been initiatives for students to acquire proper 21st century skills in association with technology in Turkey for a long time, research on the information, media and technology skills of sport sciences undergraduates is limited. This study examines the competency levels of sport science undergraduates on information, media and technology skills, and the relationship between their competency levels and certain variables such as gender, departments, grades, personal computer (PC) possession and internet access. In the process of the implementation of the Information, Media and Technology Skills Competency scale, the sample of the study was composed of 298 sport sciences undergraduates. In the analysis of the data obtained from the scale, frequency, percentage, arithmetic mean and standard deviation values were used in the central and prevalence measurements. According to the results of the scale; sport sciences undergraduate students considered themselves to be moderate in their information, media and technology skills. While the highest score of the students was of

* Assistant Professor, Sivas Cumhuriyet University, Faculty of Education, Sivas/Turkey. esinnhazar@gmail.com, ORCID: https://orcid.org/0000-00032986-696X. (Corresponding Author).

** Research Assistant, Sivas Cumhuriyet University, Faculy of Sport Sciences, Sivas/Turkey. burhanozkurt@cumhuriyet.edu.tr, ORCID: https://orcid.org/0000-0001-9745-9624. 
communication and collaboration; programming skills were emerged as the weakest dimension. It was found that there are significant correlations between their competency levels and certain variables such as grade, PC possession and internet access.

Keywords: Information, Media, Sport Sciences, Skill, Technology. 


\section{SPOR BİLİMLERİ ÖĞRENCİLERİNIN BİLGİ, MEDYA VE TEKNOLOJİ BECERILERİ}

\section{ÖZ}

Türkiye'de uzun süredir öğrencilerin teknolojiye ilişkin 21. yüzyıl becerilerini kazanmalarna yönelik girişimler olmakla birlikte, spor bilimleri lisans öğrencilerinin bilgi, medya ve teknoloji becerileri üzerine araştırmalar sinırlıdır. Bu çalışma, spor bilimleri lisans öğrencilerinin bilgi, medya ve teknoloji becerileri konusundaki yeterlilik düzeylerini ve yeterlilik düzeyleri ile cinsiyet, devam ettikleri bölüm, sinıf, kişisel bilgisayar (PC) sahibi olma ve internet erişimi gibi belirli değişkenler arasındaki ilişkiyi incelemektedir. Çalışmada kullanılan Bilgi, Medya ve Teknoloji Becerileri Yeterlilik Ölçeğinin uygulanması sürecinde araştırmanın örneklemini 298 spor bilimleri lisans öğrencisi oluşturmuştur. Ölçekten elde edilen verilerin analizinde merkezi ve yaygınlık ölçümlerinde frekans, yüzde, aritmetik ortalama ve standart sapma değerleri kullanılmıştır. Ölçek sonuçlarına göre; spor bilimleri lisans ögrrencileri bilgi, medya ve teknoloji becerilerinde kendilerini orta düzeyde yeterli görmektedir. Öğrencilerin en yüksek puanı aldıkları beceri boyutu iletişim ve işbirliği olarak belirlenen çalışmada, programlama becerileri en zayıf boyut olarak ortaya çıkmıştır. Yeterlilik düzeyleri ile öğrencilerin devam ettikleri sinıf düzeyleri, bilgisayar sahibi olma ve internet erişimi gibi bazı değişkenler arasında anlamlı ilişkiler olduğu sonucuna ulaşılmıştır.

Anahtar Kelimeler: Bilgi, Medya, Spor Bilimleri, Beceri, Teknoloji. 


\section{INTRODUCTION}

As new developments in information communication technologies (ICT) emerge, educational practices are constantly seeking innovation. Demand for labour in $21^{\text {st }}$ century economies is directed to individuals with technological knowledge, skills and creativity. It can be said that the learning paradigm of the $21^{\text {st }}$ century is based on the students who are educated with the skills, knowledge and expertise needed to succeed in the digital economy (Kivunja, 2014).

Information and Communication Technologies are available in every aspect of our daily lives. With the widespread Internet, smartphone and computer use, today's people encounter more information than ever in a variety of formats. Children and the youth namely "digital natives" access information whenever they wish and communicate using digital tools. Technology has found its way in a variety of educational settings in higher education as well. Currently, universities around the world are investing heavily in new generation technologies to equip students with the skills needed to educate them as productive individuals in the $21^{\text {st }}$ century digital world. Even though students are already operating well in the digital contexts outside the curriculum, it is the duty of education to integrate technology into learning-teaching processes and curricula, to teach students how to evaluate, interpret and effectively use information. As there are not many researches on the sport sciences students' information, media and technology skills, this study aims to explore the competency levels of undergraduates of sport sciences faculty on the information, media and technology skills.

\section{INFORMATION, MEDIA AND TECHNOLOGY SKILLS}

The $21^{\text {st }}$ Century Skills Partnership (P21) which was founded in 2002 in the United States and funded by the Ministry of Education, identified the skills that must be acquired in the 21st century and defined how learning should be in our age and guided schools in this direction (Fox, 2011). In the 21 $1^{\text {st }}$ century skills framework developed by P21, ICT related skills are conceptualized as information, media and technology skills. These skills cover; 
1. Information literacy which includes access to information, critical evaluation, and appropriate and correct use of information.

2. Media literacy which includes the ability to interpret, analyse and create new media products.

3. Information and communication technologies literacy which involves the effective use of technology to investigate, organize, evaluate and communicate information (Trilling, Fadel, 2009).

Many terms such as digital literacy, digital competence, and ICT literacy are used to describe the information, media and technology skills but they generally cover skills and competences related to the use of digital technologies (Ilomäki et al., 2011). A Digital Competence Framework (DigComp) has been developed by the European Commission to create a European consensus on the elements of digital competence and to contribute to a better understanding of digital competence and the framework is divided into five areas: Information and Data Literacy, Communication and Collaboration, Digital Content Creation, Safety and Problem Solving. In this framework, digital competence is defined as a set of knowledge, skills and attitudes towards the use of ICT that citizens should have in order to achieve goals related to employment, employability, learning, leisure and citizenship participation (Siiman et al., 2016). The key components of digital competence in 5 areas are defined as below: 
Esin HAZAR, Burhan ÖZKURT

Table 1. The Key Components of Digital Competence

Digital Competence Framework

1) Information and Data Literacy: To articulate information needs, to locate and retrieve digital data, information and content. To judge the relevance of the source and its content. To store, manage, and organise digital data, information and content.

2) Communication and Collaboration: To interact, communicate and collaborate through digital technologies while being aware of cultural and generational diversity. To participate in society through public and private digital services and participatory citizenship. To manage one's digital identity and reputation.

3) Digital Content Creation: To create and edit digital content To improve and integrate information and content into an existing body of knowledge while understanding how copyright and licences are to be applied. To know how to give understandable instructions for a computer system.

4) Safety: To protect devices, content, personal data and privacy in digital environments. To protect physical and psychological health, and to be aware of digital technologies for social well-being and social inclusion. To be aware of the environmental impact of digital technologies and their use.

5) Problem Solving: To identify needs and problems, and to resolve conceptual problems and problem situations in digital environments. To use digital tools to innovate processes and products. To keep up-to-date with the digital evolution

(European Union Science Hub, 2019)

One of DigComp's key objectives is to plan training and education initiatives to promote the digital competence of specific target groups. In addition, DigComp provides a common language for defining key areas of digital competence and a joint reference at European level (Ferrari, 2013). DigComp aims to create a common understanding of the digital competences that citizens need in today's society and to serve as a guide for the reliable and critical use of all areas of life (Kluzer, Rissola, 2015). The present study used the skills and dimensions to which those skills belong to in this framework in order to evaluate self-report of the sport sciences students related to those skills.

\subsection{Information, Media and Technology Skills and Sport Sciences}

Information, media and technology skills provide students with a great power to enhance their thinking, learning, communication, and collaboration and production skills. However, in order to utilize this power, students should first learn the skills needed to comprehend, 
manage and utilize this information, media and technology (Trilling, Fadel, 2009).

Information, media and technology skills have been identified as critical skills in the 21st century higher education institutions since the world became digital. These skills can help students' access information, become self-directed and control their learning. There are researches suggesting that most undergraduate students can access digital resources but those resources are often under-utilized because of lack of these skills among students (Malanga, Chigona, 2018). The mastery in the technology-based tools is as required in Sport Sciences as in the other academic branches since "the use of data and media, the design of models, the analysis of systems etc. need the proper use of tools and concepts developed and available in technology" (Baca, 2006). This is why ICT have become an important component of sports sciences curricula and instruction together with the works of teachers of physical education, sport managers and athletic coaches (Kocak, 2003).

Sports scientists need a well-developed theoretical understanding in a lot of disciplines such as physiology, exercise prescription, nutrition and anatomy and to promote their professional practice. In this constant changing world, it is hard to ensure sport science students to develop necessary theoretical knowledge on their owns. The increasing importance of knowledge in ICT skills for career perspectives of sports science undergraduates has implications in curricula. Technology integration in higher education is quite much standard in contemporary study programs on the university level. At higher education level, compulsory ICT courses have been offered to help non-computing majors keep up with technology and use computing to follow their career goals (Sweat-Guy, Lownes-Jackson, 2010). In order to compete and become successful in the sector of sports, digital technologies should be effectively made use of during the course of education.

Courses related to ICT are among the compulsory courses in the Turkish higher education institutes and students attend these courses for two semesters for undergraduate programs in sports sciences faculties. By the end of the first semester, the students of physical education teaching are expected to learn about information technologies and information-processing thinking, problem solving 
concepts and approaches, algorithms and flowcharts, computer systems, basic concepts of software and hardware, basics of operating systems, current operating systems, file management, utilities, word processing programs, calculation / table / graphical programs, presentation programs, Web designing, communication and collaboration technologies; safe internet use, information ethics and copyrights. And by the end of the third semester they should acquire the information technologies in education; teaching process and classification of instructional technologies, theoretical approaches to instructional technologies, new approaches in learning approaches, current literacy, instructional technologies as tools and materials, design of instructional materials, designing thematic teaching materials, creation of field-specific object warehouse, and evaluation of instructional material criteria. As for the departments of athletic coaching and sport management, the students are expected to gain basic computer usage (literacy) skills and to recognize and use basic computer concepts, commercial and open source visual operating systems, internet use, commercial and open source word processing applications, spread sheet programs, presentation programs, database programs, web page design - applications and multimedia programs (Yükseköğretim Kurumu, 2019).

Along with the outcomes and the content of these compulsory courses, sports sciences students have been using digital devices for academic purposes as well. For example, they are supposed to use ICT to prepare assignments using office automation software, to analyse data via statistical packages, to communicate through e-mail, to access information access by search engines (Shiffett et al., 2001).

To prepare ICT-proficient sport sciences students ready for the 21st knowledge world, digital devices in sport sciences are widely used. Technologies such as pedometers to count steps, heart rate monitors to design instruction and training, digital video to monitor and provide feedback may offer alternative physical activities and new fitness programs and practical professional competences (Keogh et al., 2017).

As a result, students in sports sciences departments should gain information, media and technology skills with a view to exploiting ICT for academic purposes during their studies, and to becoming sufficiently competent in ICT in order to catch up with the needs of 
their future professional careers (Papastergiou, 2010). In order to achieve success and quality in the field of sports, the use of information and communication technologies is important in both the theoretical and practical sports education, while offering the flow of information in sports education which is given both theoretical and practical in order to attain success and quality in sports discipline today (Yücel, Devecioğlu, 2011).

The present study attempts to find out whether undergraduates of sport sciences faculty acquire the information, media and technology skills having been taught through compulsory courses in their academic lives. The aims of this study can be summarized as below:

- To explore sport sciences students' self-efficacy levels related to information, media and technology skills

- To explore whether students' self-efficacy levels related to information, media and technology skills differ depending on gender, the department they are part of, grade, PC possession and internet access?

\section{METHODOLOGY}

\subsection{Participants}

The participants were 298 sport sciences undergraduate students studying in first, second, third and fourth grades in 2019- 2020 academic year, of whom 190 were male and 108 females. The students attended 3 different departments in the faculty as Physical Education Teaching, Athletic Coaching and Sport Management (Table 2).

\subsection{Instrument}

The participants in this survey completed the Information, Media and Technology Skills Competency Scale, developed by Hazar (2018) which assesses the subject's perceived ability in terms of information and data literacy, communication and collaboration, digital content creation, programming, safety and problem solving. The scale comprises items such as 'sharing information and content on the internet' and 'solving technical problems using the internet'. The scale 
consisted of two parts. The first part elicited biographical information (e.g. gender, grade). The participants were asked to rate on a fivepoint scale $(1=$ never, $2=$ Rarely, 3 = Sometimes, 4 =Usually, $5=$ Always) in the second part. The scale consisted of 23 questions. The total sum of the responses could range from 23 to 115. Students' competency levels according to the average scores of the scale rated as 1 - 1.80 Poor, 1.81 - 2.60 Insufficient, $2.61-3.40$ Medium, $3.41-4.20$ Sufficient, 4.21 - 5.00 Very Adequate.

\subsection{Procedure}

For the application of the scale, the researchers informed the students who would participate in the survey to ensure their permission for the research to be administered. The period of application of the scale was at the end of the first semester between December and January.

\subsection{Data Analysis}

Data analyses were conducted using SPSS 21.0. The reliability for the Information, Media and Technology Skills Competency Scale was assessed using Cronbach's alpha coefficient. Methods of descriptive statistics were used for the description of the examined variables according to the gender, department, PC possession, internet access and the grade of the participants. To examine the possible differences between different groups and to control the main assumptions of the research, inductive statistics ( $\mathrm{t}$ test, ANOVA) were applied.

\section{RESULTS}

\subsection{Demographic Information}

In this section, findings relevant to personal information in the scale applied to sport sciences undergraduate students are presented. The gender of the participants, the department they enrol and grade they attend, PC possession and internet access were calculated as frequency (f) and percentage (\%). 
Table 2. Demographic Information

\begin{tabular}{lll}
\hline Demographic Information & $\mathrm{f}$ & $\%$ \\
\hline Gender & 108 & 36.2 \\
\hline Female & 190 & 63.8 \\
\hline Male & & \\
\hline Department & 115 & 38.6 \\
\hline Physical Education Teaching & 105 & 35.2 \\
\hline Coaching & 78 & 26.2 \\
\hline Sport Management & & \\
\hline Grade & 84 & 28.2 \\
\hline 1,00 & 73 & 24.5 \\
\hline 2,00 & 70 & 23.5 \\
\hline 3,00 & 71 & 23.8 \\
\hline 4,00 & & \\
\hline PC Possession & 156 & 52.3 \\
\hline Possessed & 142 & 47.7 \\
\hline Not Possessed & & \\
\hline Internet Access & 117 & 39.3 \\
\hline Limited & 181 & 60.7 \\
\hline Limitless & 298 & 100 \\
\hline Total & & \\
\hline
\end{tabular}

Table 2 shows that majority of the respondents, 190 (63. 8\%) were males, while 108 (36. 2\%) was females. For the departments students enrol, 115 (38, 6\%) were from the Physical Education Teaching, 105 $(35.2 \%)$ were from the athletic coaching, while 78 (26.2\%) were from the Sport Management. Regarding grade distribution, 84 (28.2\%) were first grade students, 73(24.5) were second grade, 70(23.5) were third grade, 71(23.8) were fourth grade. 156 students (52.3\%) owned PC and 181students (60.7\%) had limitless internet Access. 


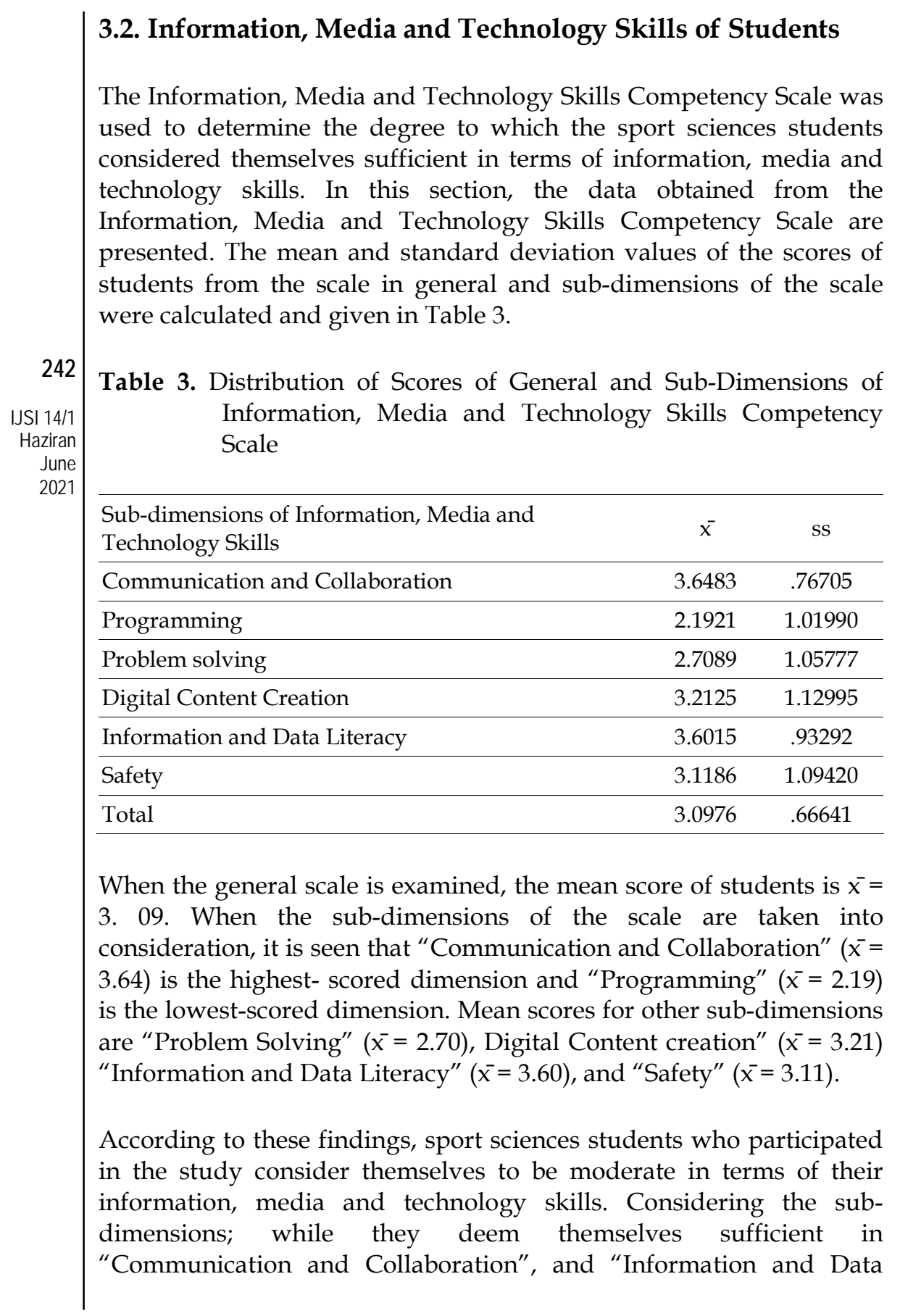


Literacy" sub-dimensions, they consider themselves moderate in "Problem Solving", "Digital Content Creation" and "Safety" subdimensions. In the "Programming" sub-dimension, students affirmed themselves as insufficient.

According to the arithmetic means, the item with the highest arithmetic mean $(\bar{x}=4.1)$ appear to be "Using instant messaging tools" (Item 4), and the item with the lowest mean $\left(\mathrm{x}^{-}=2.12\right)$ is "using at least one programming language efficiently" (Item 8). Students' competency levels according to the average scores of the scale are presented in Table 4.

Table 4. Students' competency levels according to the information, media and technology skills competency scale

\begin{tabular}{|c|c|c|c|c|}
\hline Points & Scale & $\mathrm{n}$ & $\%$ & Cumulative $\%$ \\
\hline $1.00-1.80$ & Very Poor & 6 & 2 & 2 \\
\hline $1.81-2.60$ & Insufficient & 65 & 21.8 & 23.8 \\
\hline $2.61-3.40$ & Moderate & 129 & 43.3 & 67.1 \\
\hline $3.41-4.20$ & Sufficient & 83 & 27.9 & 95 \\
\hline $4.21-5.00$ & Very Adequate & 15 & 5 & 100 \\
\hline
\end{tabular}

Students' competency levels according to the average scores of the scale show that there are only six students in the bottom and 15 students in the top. Across all male participants $(n=190)$ the information, media and technology skills overall mean for the selfreported indicators was 3.1 and standard deviation was .67. The female participants $(n=108)$ had on average 3.08 , with a standard deviation of .64 (Table 5).

For the participants who possess PC $(\mathrm{n}=156)$, the information, media and technology skills overall mean was 3.27 and standard deviation was .64. The participants not possessing PC $(n=142)$ had on average 2.9 , with a standard deviation of .63 (Table 6). 
Table 5. Information, Media and Technology Skills - Male-Female

\begin{tabular}{llcc}
\hline \multicolumn{1}{c}{ Points } & \multicolumn{1}{c}{ Scale } & Male $n$ & Female $n$ \\
\hline $1.00-1.80$ & Very Poor & 5 & 1 \\
\hline $1.81-2.60$ & Insufficient & 37 & 28 \\
\hline $2.61-3.40$ & Medium & 84 & 45 \\
\hline $3.41-4.20$ & Sufficient & 53 & 30 \\
\hline $4.21-5.00$ & Very Adequate & 11 & 4 \\
\hline $\bar{x}$ & & 3.10 & 3.08 \\
\hline
\end{tabular}

Table 6. Information, Media and Technology Skills - PC Possession

\begin{tabular}{llll}
\hline \multicolumn{1}{c}{ Points } & \multicolumn{1}{c}{ Scale } & \multicolumn{1}{c}{ Possessed } & Not Possessed \\
\hline $1.00-1.80$ & Very Poor & 2 & 4 \\
\hline $1.81-2.60$ & Insufficient & 21 & 44 \\
\hline $2.61-3.40$ & Medium & 68 & 61 \\
\hline $3.41-4.20$ & Sufficient & 57 & 26 \\
\hline $4.21-5.00$ & Very Adequate & 11 & 4 \\
\hline $\bar{x}$ & & 3.27 & 2.9 \\
\hline
\end{tabular}

For the students of physical education teaching department $(n=115)$, the information, media and technology skills overall mean was 3.05 with a standard deviation of .61. The participants who enrol in coaching department $(n=105)$ had an average of 3.17 with a standard deviation of .71. The students of sport management department $(\mathrm{n}=$ 78) had an average of 3.04 with a standard deviation of .67 (Table 7).

Table 7. Information, Media and Technology Skills - Students' Department

\begin{tabular}{lllll}
\hline \multicolumn{1}{c}{ Points } & \multicolumn{1}{c}{ Scale } & $\begin{array}{c}\text { Physical Education } \\
\text { Teaching }\end{array}$ & Coaching & $\begin{array}{c}\text { Sport } \\
\text { Management }\end{array}$ \\
\hline $1.00-1.80$ & Very Poor & 0 & 3 & 3 \\
\hline $1.81-2.60$ & Insufficient & 26 & 22 & 17 \\
\hline $2.61-3.40$ & Medium & 56 & 38 & 35 \\
\hline $3.41-4.20$ & Sufficient & 28 & 31 & 24 \\
\hline $4.21-5.00$ & Very Adequate & 5 & 8 & 2 \\
\hline $\bar{x}$ & 3.05 & 3.17 & 3.04 \\
\hline
\end{tabular}


For $1^{\text {st }}$ grade students $(\mathrm{n}=84)$, the information, media and technology skills overall mean was 2.94 with a standard deviation of .73 . The participants who attend $2^{\text {nd }}$ grade $(n=73)$ had an average of 3.20 with a standard deviation of $.66 .3^{\text {rd }}$ grade students $(n=70)$ had an average of 3.22 with a standard deviation of .62. The participants who attend $4^{\text {th }}$ grade $(n=71)$ had an average of 3.04 with a standard deviation of .57 (Table 8 ).

Table 8. Information, Media and Technology Skills - Students' Grades

\begin{tabular}{llllll}
\hline \multicolumn{1}{c}{ Points } & \multicolumn{1}{c}{ Scale } & $\begin{array}{c}1^{\text {st }} \\
\text { Grade }\end{array}$ & \multicolumn{1}{c}{$\begin{array}{c}2^{\text {nd }} \\
\text { Grade }\end{array}$} & $\begin{array}{c}3^{\text {rd }} \\
\text { Grade }\end{array}$ & $\begin{array}{c}4^{\text {th }} \\
\text { Grade }\end{array}$ \\
\hline $1.00-1.80$ & Very Poor & 4 & 0 & 0 & 2 \\
\hline $1.81-2.60$ & Insufficient & 22 & 17 & 13 & 13 \\
\hline $2.61-3.40$ & Medium & 39 & 26 & 30 & 34 \\
\hline $3.41-4.20$ & Sufficient & 13 & 26 & 23 & 21 \\
\hline $4.21-5.00$ & Very Adequate & 6 & 4 & 4 & 1 \\
\hline $\bar{x}$ & & 2.94 & 3.20 & 3.22 & 3.04 \\
\hline
\end{tabular}

Across all participants who have limited access to internet $(\mathrm{n}=117)$, the information, media and technology skills overall mean was 2.93 with a standard deviation of .66. The participants who have limitless internet access $(n=181)$ had an average of 3.19 with a standard deviation of .65 (Table 9).

Table 9. Information, Media and Technology Skills - Students' Internet Access

\begin{tabular}{llll}
\hline Points & \multicolumn{1}{c}{ Scale } & \multicolumn{1}{c}{ Limited } & \multicolumn{1}{c}{ limitless } \\
\hline $1.00-1.80$ & Very Poor & 6 & 0 \\
\hline $1.81-2.60$ & Insufficient & 30 & 35 \\
\hline $2.61-3.40$ & Medium & 54 & 75 \\
\hline $3.41-4.20$ & Sufficient & 26 & 58 \\
\hline $4.21-5.00$ & Very Adequate & 2 & 13 \\
\hline $\bar{x}$ & & 2.93 & 3.19 \\
\hline
\end{tabular}




\begin{abstract}
$\mid \begin{aligned} & \text { The results of the } t \text { tests and the one-way ANOVA, which were used } \\ & \text { to compare the self-estimation of the information, media and } \\ & \text { technology skills level among different groups, are listed in Table } 10 . \\ & \text { Statistically significant difference was found between the grades of the } \\ & \text { students, the state of PC possessions and internet access. }\end{aligned}$
Table 10. Information, Media and Technology Skills $\mathrm{T}$ Test and ANOVA Summary Table

\begin{tabular}{|c|c|c|c|}
\hline Groups & $\mathrm{df}$ & t or $F$ & $\mathrm{p}$ \\
\hline Gender & 296 & -.341 & .733 \\
\hline Department & 297 & 1.201 & .302 \\
\hline Grade & 297 & 3.225 & $.023^{*}$ \\
\hline Pc Possession & 296 & 5.036 & $.000^{*}$ \\
\hline Internet Access & 296 & -3.342 & $.001^{*}$ \\
\hline
\end{tabular}

As deduced from Table 10, when the gender variable considered, the two groups did not differ significantly in their competency levels. As for the departments the students enrol, significant differences were still absent in information, media and technology skills. However, as derived from Table 10 students' grades, the state of PC possession and internet access exhibited significant difference. The state of students' possessing PC and having limitless internet access exhibited significantly higher information, media and technology skills selfefficacy. As the one-way ANOVA test showed statistically significant difference among the students in different grades, to clear from which grades the difference come from, one of the Post Hoc Tests, Tukey, was administered as the variances were homogenous. According to the results of multiple comparison test, 3rd grade students' selfefficiency levels towards information, media and technology skills were significantly higher than the 1 st grades and there was a significant difference between these two groups.
\end{abstract}

\title{
4. DISCUSSION
}

The findings showed that the sport sciences students took part in this study felt they were moderate on the information, media and technology skills, which is consistent with the results of Ratliff (2009) who concluded that noncompeting college majors often lack these 
Information, Media and Technology Skills of Sport Sciences Students

skills and are insufficient in searching online, performing presentations or analysing data.

Only $5 \%$ of the students reported themselves to be adequate overall on their information, media and technology skills, and $23 \%$ of the students considered themselves poor or insufficient in these skills. Although there are two compulsory courses related to information, media and technology skills in undergraduate programs of the Faculty of Sport Sciences in Turkey and the content of these courses are quite relevant to these skills, very few students seem to acquire sufficient knowledge regarding these skills. That the most scored sub dimension is communication and collaboration may result from the fact that students are highly engaged in social networking. (Hammond et al., 2009).

Although it is expected that the students are digital natives and technologically knowledgeable due to the ICT classes they attended during their secondary and tertiary education, they seem to have low scores on programming sub dimension. It may result from the fact that those students could not attend the Information Technologies and Software course started to be implemented in Turkey in 2012 in which software and programming training subjects were added and basic programming training was started to be given starting from the 5th grade. Or even if they had the chance to have these classes, as stated by Akpinar and Altun (2014), this may be due to the general use of computer automation (office automation) applications and the lack of a curriculum based on programming and design.

There seem to be no significant differences between the results of male and female students. Although some studies (Yıldız, Seferoğlu, 2014; Yilmaz, Ersoy, 2016) suggest that there is a significant relationship between gender and access to information communication technologies, other studies (Dinçer, 2017; Elçi, Sarı, 2016; Mısırlı, 2013; Yilmaz, Ersoy, 2016) did not reveal a significant difference between the competence levels of female and male students.

When comparing the information, media and technology skills competency levels of students who possess PC to those who do not, findings show that PC ownership has a significant effect on students' scores. When PC possession variable considered, the two groups differ significantly in their competency levels as stated by Misirlı 
(2013) that students' possessing PC increased their scores in terms of technology skills.

As for the departments the students enrol, no statistically significant difference was found between the results even though a study conducted by Şimşek (2018) found out some differences among the results of the students' scores towards information and communication technologies in different departments of sport sciences faculties.

When comparing the results of the students who have limited and limitless access to internet, a significant difference was revealed. The students having limitless internet access exhibited significantly higher information, media and technology skills self-efficacy and the two groups differ significantly in their competency levels. This finding is corroborated by Ajuwon (2003) who found out that insufficient Internet use had a negative impact on the ICT skills of undergraduate students.

There was a significant difference among the results of the students in different grades. The mean scores of the $1^{\text {st }}$ grade student were lower than the scores of the other grades. 3rd grade students' self-efficiency levels towards information, media and technology skills were significantly higher than the 1st grades. The reason for this may be the fact that the first graders could not have finished the ICT course during the semester yet, although some other studies (Şimşek, 2018) suggest the contrary that the younger the students, the more positive attitudes towards information and communication technologies.

\section{CONCLUSION}

The research revealed that undergraduate students of the faculty of sport sciences are moderate in information, media and technology skills and more initiatives are a requisite for the students to acquire these skills. According to the results of the study these skills do not depend upon gender and departments of the participants. However, students who have PC and limitless internet access are more sufficient in these skills. Furthermore, the findings show that the $1^{\text {st }}$ graders reported themselves less sufficient in these skills compared to the $3^{\text {rd }}$ graders. 
Information, Media and Technology Skills of Sport Sciences Students

The study revealed that the highest averaged sub dimension was communication and collaboration. The lowest rate of information, media and technology skills was in the sub dimension of programming.

Prospective sport scientists should improve themselves and meet the demands of the age if they want to live and work in $21^{\text {st }}$ century knowledge world. In the present study, the majority of the students reported themselves as insufficient in information, media and technology skills. As the curricula of the courses related to these skills are satisfactory enough in terms of content, there may be some wrongdoing in the teaching learning process or the in the duration of the courses. Effective use of information and communication technologies in the faculties of sport sciences as in other higher education institutions will be beneficial for future sport scientists since ICT is a motivating element to acquire both theoretical knowledge and psychomotor skills. To achieve this, faculties of sport sciences should be equipped with the adequate technological facilities and the use of those should be integrated into learning teaching process as an interdisciplinary subject. 


\section{REFERENCES}

Ajuwon, Grace Ada (2003). “Computer and Internet Use by First Year Clinical and Nursing Students in a Nigerian Teaching Hospital". Medical Informatics and Decision Making, 3(1), 1-11.

Baca, Arnold (2006). "Computer Science in Sport: An Overview of History, Present Fields and Future Applications “. International Journal of Computer Science in Sport, 4(1), 25-35.

Dinçer, Serkan (2017). “Ortaokul Öğrencilerinin Bilgisayar Okuryazarlık Düzeylerinin Belirlenmesi ve Ölçme-Değerlendirme Araçlarının Yapısı". lkögretim Online, 16(3) 1330-1342.

Elçi, Abdullah Cemil; Sarı, Mediha (2016). “Bilişim Teknolojileri ve Yazılım Dersi Öğretim Programına Yönelik Öğrenci Görüşlerinin Dijital Vatandaşlık Bağlaminda Incelenmesi". Çukurova Üniversitesi Sosyal Bilimler Enstitüsü Dergisi, 25(3), 87-102.

European Union Science Hub, (2019). "The Digital Competence Framework 2.0", (https:/ / ec.europa.eu/jrc/en/digcomp/digital-competence-framework) (Accessed on 29.12.2019).

Ferrari, Anusca (2013). “DIGCOMP: A Framework for Developing and Understanding Digital Competence in Europe". Y. Punie, Yves; Breco, Barbara (Eds.). JRC Scientific and Policy Reports (50), Seville: European Commission Joint Research Centre. (http://digcomp.org.pl/wpcontent/uploads/2016/07/DIGCOMP-1.0-2013.pdf 05/01/2017) (Accessed on 03.10.2018).

Fox, Michele O'Conor (2011). “Implementıng 21st Century Skills: A Paradox in a Traditional World of Education?", (Unpublished Doctoral Dissertation), College of Saint Elizabeth, USA.

Hammond, Michael; Crosson, Sue; Fragkouli, Elpiniki; Ingram, Jennifer; Johnston-Wilder, Peter; Johnston-Wilder, Sue; Kingston, Yvette; Pope, Melanie; Wray, David (2009). "Why Do Some Student Teachers Make Very Good Use of ICT? An Exploratory Case Study". Technology, Pedagogy and Education, 18(1), 59-73.

Ilomäki, Liisa; Kantosalo, Anna; Lakkala, Minna (2011). “What Is Digital Competence?". (https://helda.helsinki.fi/bitstream/handle/10138/154423 /Ilom_ki_etal_2011_What_is_digital_competence.pdf?sequence=1) (Accessed on 14.12.2018).

Keogh, Justin; Gowthorp, Lisa; McLean, Michelle (2017). “Perceptions of Sport Science Students On the Potential Applications and Limitations of Blended Learning in Their Education: A Qualitative Study". Sports Biomechanics, 16(3), 297-312. 
Information, Media and Technology Skills of Sport Sciences Students

Kivunja, Charles (2014). “Do You Want Your Students to Be Job-Ready with 21st Century Skills? Change Pedagogies: A Pedagogical Paradigm Shift from Vygotskyian Social Constructivism To Critical Thinking, Problem Solving And Siemens' Digital Connectivism". International Journal of Higher Education, 3(3), 81 .

Kluzer, Stefano; Rissola, Gabriel (2015). "Guidelines on the Adoption of DigComp". (http://www.telecentre-europe.org/wpcontent/uploads/2016/02/TE-Guidelines-on-theadoption-ofDIGCOMP_Dec2015.pdf) (Accessed on 04.07.2018).

Kocak, Settar (2003). "Computer Attitudes and Competencies in Physical Education and Sport". International Council for Health, Physical Education, Recreation, Sport and Dance, 39(1), 49-52.

Malanga, Donald; Chigona, Wallace (2018). “Digital Information Literacy of Undergraduate Students in Higher Education Institutions in Malawi: Challenges and Policy Implications". (https://papers.ssrn.com/sol3 / papers.cfm?abstract_id=3274573) (Accessed on 10.10.2019).

Mears, Derrick; Hansen, Lisa; Fine, Patrick; Lawler, Phil; Mason, Kim; Richardson, Cheryl (2009). Appropriate Use of Instructional Technology in Physical Education. Reston, VA: National Association for Sport and Physical Education.

Misırlı, Zeynel Abidin (2013). “Ortaokul Öğrencilerinin Eğitim Teknolojisi Standartlarına Ilişkin Yeterliklerinin Incelenmesi", (Unpublished Doctoral Dissertation), Anadolu University, Institute of Educational Sciences, Eskişehir.

Papastergiou, Marina (2010). “Enhancing Physical Education and Sport Science Students' Self-Efficacy and Attitudes Regarding Information and Communication Technologies Through a Computer Literacy Course". Computers E Education, 54(1), 298-308.

Ratliff, Victoria (2009). “Are College Students Prepared for a Technology-Rich Learning Environment". MERLOT Journal of Online Learning and Teaching, 5(4), 689-702.

Shiffett, Bethany; Murdach, Charles; Meschke, Shane; Megginson, Nancy (2001). "A Presence on the Web". Physical Educator, 58(4), 175.

Siiman Leo; Mäeots, Mario; Pedaste, Margus; Simons, Robert-Jan; Leijen, Äli; Rannikmäe, Miia; Võsu, Külli; Timm, Maarja (2016). “An Instrument for Measuring Students' Perceived Digital Competence according to the Digcomp Framework". International Conference on Learning and Collaboration Technologies, 233-244, Springer International Publishing.

Şimşek, Abdullah (2018). "Spor Eğitimi Alan Üniversite Öğrencilerinin Bilgi ve İletişim Teknolojilerine Yönelik Tutumlarının Belirlenmesi", (Unpublished Master Thesis), Frrat University, Elazı ̆. 
Sweat-Guy, Retta; Lownes-Jackson, Millicent (2010). "An Examination of Students' Self-Efficacy Beliefs and Demonstrated Computer Skills". Issues in Informing Science and Information Technology, 7, 285-295.

Trilling, Bernie; Fadel, Charles (2009). 21st Century Skills: Learning for Life in Our Times. John Wiley \& Sons.

Yıldız, Hatice; Seferoğlu, Süleyman Sadi (2014). “İlköğretim Öğrencilerinin Sayısal Uçurum Düzeyleriyle İlgili Görüşlerinin Çeşitli Değişkenler Açısından Incelenmesi". Hacettepe Üniversitesi Eğitim Fakültesi Dergisi, 29(3), 220-235.

Yılmaz, Firat; Ersoy, Ali (2016). "Besinci Sınıf Ögrencilerinin Bit Erisim Olanakları ve Bit Okuryazarlık Düzeyleri Arasındaki Dijital Bölünme". Journal of Educational Science, 2(2), 16-32.

Yu, Chia-Chen (2007). "Important Computer Competencies for Sport Management Professionals". International Journal of Applied Sports Sciences, 19(1).

Yücel, Ali; Devecioğlu, Sebahattin (2012). "Spor Eğitiminde Bilgi ve İletişim Teknolojilerinin Kullanimi”. Sport Sciences, 7 (2), 1-17.

Yükseköğretim Kurumu, (2019). “Beden Eğitimi ve Spor Öğretmenliği Lisans Programi”. (https://www.yok.gov.tr/Documents/Kurumsal/egitim_ogretim _dairesi/Yeni-Ogretmen-Yetistirme-Lisans-Programlari/Beden_Egitimi_ve_ Spor_Ogretmenligi_Lisans_Programi.pdf) (Accessed on 11.03.2020). 
Information, Media and Technology Skills of Sport Sciences Students

\section{ÖZET}

Bilgi iletişim teknolojilerinde ortaya çıkan gelişmeler eğitim uygulamalarında da yenilikleri beraberinde getirmiştir. 21. yüzyıl ekonomilerinde işgücü talebi teknolojik bilgi, beceri ve yaratıcılığa sahip bireylere yöneliktir. 21. yüzyılın öğrenme paradigmasının dijital ekonomide başarılı olmak için ihtiyaç duyulan beceri, bilgi ve uzmanlıkla yetiştirilen öğrencilere dayandığı söylenebilir. Günlük hayatımızın her alanında kendine yer edinen İnternet, akıllı telefon ve bilgisayarlar bilgiye erişimi her zamankinden daha kolay hale getirmiştir. Çocuklar ve gençler, yani "dijital yerliler" bilgiye istedikleri zaman erişip dijital araçlarla iletişim kurabilmektedir. İlk ve orta öğretim gibi yükseköğretimde de teknoloji, çeşitli eğitim ortamlarında yerine almıştır. Şu anda, dünyanın dört bir yanındaki üniversiteler, öğrencileri 21. yüzyılın dijital dünyasında üretken bireyler olarak eğitmek ve gereken becerilerle donatmak için yeni nesil teknolojilere büyük yatırım yapmaktadır. Öğrenciler dijital ortamlarda etkin şekilde yer alsa da, teknolojiyi öğrenme-öğretme süreçlerine ve müfredata entegre etmek, öğrencilere bilgiyi nasıl değerlendireceklerini, yorumlayacaklarını ve etkili bir şekilde kullanacaklarını öğretmek eğitimin görevidir.

Tıpkı diğer akademik bölümlerde olduğu gibi spor bilimlerinde de bilgi, medya ve teknoloji becerilerinin öğrencilere kazandırılması oldukça önemlidir zira spor bilimi öğrencileri de öğretim ve araştırma amacıyla bilgi iletişim teknolojilerini kullanmaktadır. Aynı zamanda spor bilimlerinde pedometre vb. bilgisayarlı ve dijital cihazlar yaygın olarak kullanılmaktadır. Spor bilimleri öğrencilerinin bilgi, medya ve teknoloji becerilerine ait yeterlilikleri belirlemeye yönelik çok fazla araştırma bulunmadığından, bu çalışma spor bilimleri fakültesi lisans öğrencilerinin bilgi, medya ve teknoloji becerileri konusundaki yeterlilik düzeylerini ve yeterlilik düzeyleri ile cinsiyet, devam ettikleri bölüm, sınıf, kişisel bilgisayar sahibi olma ve internet erişimi gibi belirli değişkenler arasındaki ilişkiyi incelemeyi amaçlamıştır. Çalışmada kullanılan Bilgi, Medya ve Teknoloji Becerileri Yeterlilik Ölçeğinin uygulanması sürecinde araştırmanın örneklemini 298 spor bilimleri lisans öğrencisi oluşturmuştur.

Araştırma, spor bilimleri fakültesi lisans öğrencilerinin bilgi, medya ve teknoloji becerileri açısından kendilerini orta düzeyde yeterli bulduklarını göstermiştir. Çalışmada en yüksek ortalama iletişim ve işbirliği becerisinde alınırken, programlama becerisinin en zayıf boyut olarak ortaya çıktığı görülmektedir. Cinsiyet ve öğrencilerin devam ettikleri bölümler bu yeterlilikler açısından anlamlı bir fark oluşturmazken, bilgisayarı ve sınırsız internet erişimi olan öğrencilerin kendilerini daha yeterli gördükleri sonucuna ulaşılmıştır 


\begin{abstract}
Sonuç olarak çalışmaya katılan spor bilimleri öğrencilerinin çoğunluğu bilgi, medya ve teknoloji becerilerinde yetersiz oldukların belirtmişlerdir. Diğer yükseköğretim kurumlarında olduğu gibi spor bilimleri fakültelerinde de bilgi ve iletişim teknolojilerinin etkin kullanımı gelecekteki spor bilimcileri için faydalı olacaktır çünkü bilgi iletişim teknolojileri hem teorik bilgi hem de psikomotor becerileri kazanmak için motive edici bir unsurdur. Bunu başarmak için spor bilimleri fakülteleri yeterli teknolojik imkanlarla donatılmalı ve bunların kullanımı disiplinler arası bir konu olarak öğrenme öğretim sürecine entegre edilmelidir.
\end{abstract}

